\section{Przeszłość w muzeach - dwa modele reprezentacji. \\ Analiza porównawcza \\ Europejskiego Centrum Solidarności i Muzeum II Wojny Światowej w Gdańsku}

\section{Anna Ziębińska-Witek}

TEKSTY DRUGIE 2020, NR 4, S. 213-232

DOI: 10.18318/td.2020.4.12 | ORCID: 0000-0003-2682-748X

$\mathbf{R}$ ewolucja muzealna" z końca lat 8o. XX wieku przyniosła zmianę w strategiach wystawienniczych ekspozycji historycznych, jednak nie dotknęła fundamentalnych założeń filozoficznych tkwiących u ich podstaw. Postulaty „nowej muzeologii” w polskich warunkach zostały zaakceptowane głównie $\mathrm{w}$ wymiarze technologicznym, nie udała się za to transformacja głównych zadań muzeów historycznych, zwłaszcza w wymiarze poszerzonego kontaktu z publicznością. Kuratorzy niechętnie rezygnują z udzielonego im jeszcze w XIX wieku przywileju nadawania znaczeń i narzucania sensu na przeszłą rzeczywistość, wytwarzają spójne i klarowne narracje noszące złudne znamiona bezstronności i obiektywności. Twórcy unikają wszelkich niejednoznaczności lub kontrowersji, które zgodnie z założeniami „nowej muzeologii” są ze wszech miar pożądane, gdyż stanowią podstawę
Anna Ziębińska-

-Witek - dr hab., prof. UMCS, pracuje na Uniwersytecie Marii Curie-Skłodowskiej w Lublinie. Historyk-metodolog, zajmuje się muzeologią, teoretycznymi problemami wiedzy o przeszłości oraz problematyką reprezentacji historii w wizualnych dyskursach kultury współczesnej. Autorka wielu publikacji, w tym monografii: Holocaust. Problemy przedstawiania (2005), Historia w muzeach. Studium ekspozycji Holokaustu (2011) i Muzealizacja komunizmu w Polsce i Europie Środkowo-Wschodniej (2018). Stypendystka Fundacji Kościuszkowskiej (United States Holocaust Memorial Museum, Washington DC) oraz Fundacji Fulbrighta (Princeton University). 
rozumienia trudnych zjawisk historycznych oraz kształtują otwartą postawę wobec narodowej przeszłości. ${ }^{1}$

W praktyce podstawowym zadaniem narracji muzealnych jest naturalizacja związku między historią, pamięcią zbiorową i dziedzictwem kulturowym. Granice między tymi dyskursami są nieostre. Historia jako nauka (zarówno jako res gestae, jak i rerum gestarum) jest wykorzystywana do celów poznawczych, ale również do budowania spójnej tożsamości wspólnoty, konstruowania podstawowego kanonu wiedzy o przeszłości i poczucia dumy z narodowej spuścizny. Muzea są więc jednocześnie miejscami pamięci i miejscami historii, w czym nie ma nic zdrożnego, przynajmniej dopóki wiedza historyczna nie staje się instrumentem manipulacji świadomością i pamięcią zbiorową społeczeństwa.

Sam termin muzealizacja nie implikuje wykorzystywania przeszłości do celów innych niż poznawcze, gdyż oznacza fizyczne lub koncepcyjne wyodrębnienie określonego elementu z jego naturalnego lub kulturowego otoczenia i nadanie mu statusu muzealnego². Tym „elementem” może być namacalny przedmiot, zjawisko, proces historyczny lub cały fragment dziejów danej wspólnoty. Proces muzealizacji obejmuje niezbędne fazy, do których należą badania naukowe i ekspertyzy, nadawanie obiektom nowych znaczeń w obrębie wystawy, jednak podstawowym zabiegiem jest selekcja dotycząca zarówno obiektów, jak i zdarzeń wykorzystanych do budowania opowieści o przeszłości. To właśnie ten etap jest najbardziej podatny na nadużycia, gdyż odpowiednio dobrane fragmenty przeszłej rzeczywistości mogą być traktowane jako narzędzie do osiągania konkretnych, współczesnych celów. Selekcji zawsze można dokonać tak, by elementy wybrane z mnogości wydarzeń i obiektów pasowały do odgórnie założonej tezy lub postawionego sobie celu.W przypadku muzeów historycznych najczęściej chodzi o kształtowanie lub utrwalanie tożsamości danej wspólnoty, podkreślenie jej wyjątkowości i legitymizację punktu widzenia zgodnego z aktualną polityką historyczną ${ }^{3}$.

1 Więcej na ten temat: A. Ziębińska-Witek Muzea historyczne wXXI wieku: transformacja czy trwanie?, "Kultura Współczesna” 2015 nr 4, s. 106-123. D. Preziosi Philosophy and the Ends of the Museum, w: Museum Philosophy for the Twenty-first Century, ed. by H.H. Genoways, Altamira Press, Lanham, MD 2006, s. 69-78.

2 Key concepts of museology, ed. by A. Desvallées, F. Mairesse, Armand Colin, Paris 2010, s. 50-51.

3 Powyższa diagnoza nie dotyczy jedynie polskich muzeów, por. National Museum Making Histories in a Diverse Europe, http://liu.diva portal.org/smash/get/diva2:573632/FULLTEXTo1.pdf, S. 11. (20.05.2017). 
Perspektywa afirmatywna (celebrująca historię własnego narodu) realizowana jest nad wyraz chętnie w muzeach historycznych krajów postkomunistycznych. Jest to spowodowane nie tylko realnymi zagrożeniami samej idei państwa narodowego w wyniku procesów globalizacji i homogenizacji kulturowej", ale również koniecznością potransformacyjnego przedefiniowania tożsamości, określenia siebie wobec innych oraz wypracowania pożądanych relacji ze „starymi” członkami Unii Europejskiej. W tym kontekście można uznać, że w wielu krajach Europy Środkowo-Wschodniej wciąż aktualna jest "militarna” definicja muzeum historycznego, które buduje mury otaczające wspólnotę, działa jak kulturowe uzbrojenie, definiuje swojego i obcego oraz utrwala światopogląd postrzegany przez pryzmat danego narodu ${ }^{5}$. Atrakcyjność formalna ekspozycji związana ze wspomnianą wyżej „rewolucją muzealną" nie oznacza w tym przypadku nowoczesności całego przekazu, na pewno jednak wpływa na sposób percepcji treści, które - efektowne podane - mogą być postrzegane jako innowacyjne.

Wśród wielu muzeów historycznych powstałych w Polsce po transformacji są jednak i takie, które prezentują bardziej nowatorski model reprezentacji historii. W tym przypadku za atrakcyjnością formy podąża niekonwencjonalna treść. Poniżej, na przykładzie analizy dwóch muzeów historycznych otwartych w podobnym czasie w jednym mieście, zarysuję różnicę między tradycyjnym i nietradycyjnym sposobem kształtowania wystawy historycznej ${ }^{6}$. Europejskie Centrum Solidarności (ECS) i Muzeum II Wojny

4 F.S. Kaplan Making and Remaking National Identities w: A Companion to Museum Studies, ed. by S. Macdonald, Blackwell Publishing, Oxford 2006, s. 152-153.

5 National Museum Making Histories in a Diverse Europe, http://liu.diva portal.org/smash/get/ diva2:573632/FULLTEXTo1.pdf, s. 11. (20.05.2017).

6 Oba muzea zostały w ostatnich latach poddane presji wynikającej z przyczyn politycznych, sytuacja ta jednak nie jest przedmiotem analizy niniejszego tekstu. Każda wystawa historyczna, bez względu na poziom nowoczesności treści lub formy, może stać się przedmiotem ataków z bieżącej perspektywy historycznej, gdyż oceniana jest wówczas przez pryzmat doraźnych celów politycznych lub propagandowych, a nie w kontekście muzeologicznym lub poznawczym. W przypadku Muzeum II Wojny Światowej krytyce poddano koncepcję narracji uniwersalizującej doświadczenia ofiar, w Europejskim Centrum Solidarności zarzewiem konfliktu był sposób pokazania jednego z głównych bohaterów narracji (Lecha Wałęsy) oraz działania pozamuzealne prowadzone przez instytucję (np. polityczne konferencje prasowe), zob. M. Sandecki PiS chce zmienić ECS po swojemu. Minister Gliński domaga się obsady stanowisk w Centrum, "Gazeta Wyborcza Trójmiasto" 31 stycznia 2019, https://trojmiasto.wyborcza.pl/trojmiasto /7,35612,24415092,pis-chce-zmienic-ecs-po-swojemu-minister-glinski-domaga-sie.html (01.06.2020). 
Światowej (MIIWŚ)7 to instytucje powstałe już po rewolucyjnych zmianach w muzealnictwie, nowoczesne kategorie zaangażowania emocjonalnego, profesjonalnego konstruowania narracji czy doświadczenia przeszłości są w obu przypadkach dla twórców oczywistością, jednak ostateczny rezultat ich wykorzystania jest odmienny.

\section{Budynki muzealne}

Współczesne budynki muzealne nie są już klasycznymi pałacami i świątyniami, przybierają kształt modernistycznych form geometrycznych, postmodernistycznych obiektów pełnych symbolicznych odniesień lub nawiązują do popularnej architektury postindustrialnej. Są one efektem międzynarodowych konkursów, do których zgłaszają się architekci z całego świata, i stanowią bardzo istotny element muzealnego doświadczenia.

Europejskie Centrum Solidarności zostało otwarte w 2014 roku „w 34 rocznicę podpisania Porozumienia Gdańskiego, uroczystość nawiązywała do tradycyjnego wodowania statku (o „burtę" ECS rozbito butelkę cydru) ${ }^{8}$. Kształt budynku, który miał oddawać zarówno „ducha Solidarności”, jak i przemysłowy charakter otoczenia, nawiązuje do stoczni i okrętów. Elewacja przywołuje na myśl kadłub statku i jest wykonana ze specjalnego rodzaju stali (Cor-Ten, firmy Ruukki), sprawiającej wrażenie, że bryła wygląda jak pokryta rdzą. Otwarty i przeszklony fronton symbolizuje „drogę do wolności”’. Wojciech Targowski, nawiązując do architektury ECS, pisze: „[...] forma może być odczytywana w wieloraki sposób i przywodzić na myśl żeglujący okręt, a może raczej kadłub budowanego dopiero statku, albo zeskładowane blachy

7 W przypadku Muzeum II Wojny Światowej analizuję wystawę w jej pierwotnym założeniu i wykonaniu, przed zmianami wprowadzonymi przez nową dyrekcję. Liczy się dla mnie koncepcyjny zamysł twórców wystawy, a nie jej obecny kształt będący wynikiem przekształceń związanych z określoną polityką historyczną. O "korektach" ekspozycji zob. E. Flieger Nowa dyrekcja w akcji. Tak zmieniali wymowę gdańskiego Muzeum II Wojny Światowej, "Gazeta Wyborcza" 24.07.2019, https://wyborcza.pl/7,75398,25025155, nowa-dyrekcja-w-akcji-tak-zmienialiwymowe-gdanskiego-muzeum.html (12.01.2020).

8 M. Szruba Europejskie Centrum Solidarności, www.infona.pl/.../174602e6-c541-3502-8387056a2eegf446 (24.09.2016). Instytucję powołano do życia w 2007 roku decyzją ministra kultury i dziedzictwa narodowego, władz miasta Gdańska, samorządu województwa pomorskiego, NSZZ "Solidarność" i Fundacji Centrum Solidarności. Akt erekcyjny podpisano 31 sierpnia 2005 roku w 25 rocznicę obchodów Sierpnia 80.

9 Tamże. 
przygotowane do jego budowy. Dla wielu ponadczasowość stale aktualnych idei Solidarności wynika z faktu, że jeszcze się nie dopełniły, a proces ich osiaggania nie zakończył się"10. Dzieło zapoczątkowane przez „Solidarność” (samotny okręt na wzburzonym morzu) domaga się kontynuacji, polska „misja wolnościowa” jeszcze się nie wypełniła. Od pierwszej chwili, czyli od spojrzenia na budynek i jego usytuowanie, odwiedzający ma odczuć znaczenie dziejących się w tym miejscu wydarzeń oraz roli Polski w procesach historycznych przemian.

W przeciwieństwie do ECS kształt budynku Muzeum II Wojny Światowej jest niejasny i niejednoznaczny. Sami architekci (Jacek Droszcz, Bazyli Domsta) świadomie unikali bezpośredniego porównania z wojną oraz dosłownych kształtów. Ambiwalencja miała być siłą budynku, otwierać go na rozmaite interpretacje. Forma nawiązuje do tonącego okrętu, walącego się budynku, zapory, przepaści lub rakiety wbitej w ziemię. Podświetlony obiekt może kojarzyć się również ze zniczem. Jacek Droszcz mówił: „Wieża jest symbolem przyszłości - otwiera się w kierunku Nowego Miasta w Gdańsku. Po trudach zwiedzania, mamy okazję zobaczyć panoramę odbudowanego miasta. Chcieliśmy stworzyć coś uniwersalnego. Podobnie działo się w przeszłości - przestrzeń miast została znaczona takimi dominantami - dawniej były to wieże kościołów. My postawiliśmy współczesną wieżę. [...] Warto również wspomnieć o placu, który powstał przed wejściem do muzeum. Stworzyliśmy przestrzeń, w której możemy się umawiać, spotykać, ma to ogromne znaczenie miastotwórcze"11. Budynek jest niepokojący, sprawia wrażenie niestabilnego, nie pozwala na proste i optymistyczne odczytania.

\section{Zakres czasowy, narracja, kreacja bohaterów i wrogów}

Ekspozycja ECS dotyczy głównie historii „Solidarności” (rozpoczyna się w 1980 roku, a kończy upadkiem systemu komunistycznego), co jest niezwykle dogodne z perspektywy narracji tożsamościowej i heroicznej. Wydarzenia wcześniejsze (z lat 1945-1970) ograniczono do symbolicznych dat

10 W. Targowski Architektura budynku Europejskiego Centrum Solidarności, w: Wystawa stała Europejskiego Centrum Solidarności. Katalog, red. P. Golak, B. Kerski, K. Knoch, Europejskie Centrum Solidarności , Gdańsk 2014, S. 253.

11 Co o swoim projekcie Muzeum II Wojny Światowej mówiq architekci z pracowni KWADRAT, https:// archirama.muratorplus.pl/architektura/co-o-swoim-projekcie-muzeum-ii-wojny-swiatowejmowia-architekci-z-pracowni-kwadrat,67_4832.html (12.01.2020). 
1953, 1956, 1961, 1968 odnoszących się, co symptomatyczne, do aktów społecznego nieposłuszeństwa i powstań przeciwko władzy komunistycznej. Ma to swoje uzasadnienie, gdyż tożsamość narodowa i pamięć zbiorowa najchętniej odwołują się do takich momentów w historii, które umacniają pozytywny autowizerunek wspólnoty, odrzucając to, co nie przystaje do heroicznego obrazu. Trudny i skomplikowany okres komunizmu (szczególnie pod względem postaw społecznych) został okrojony i nabrał w ECS jednoznacznych wymiarów bohaterskiej przeszłości. Historia „Solidarności” pasuje tu idealnie, gdyż okres ten był iście romantycznym narodowym zrywem, działaniem z pobudek moralnych, w imię wyższych wartości. Język, którym wrażano wówczas gniew, był językiem racji moralnej ${ }^{12}$, który po transformacji zanikł. ECS powraca do tego dyskursu, przywracając jednocześnie poczucie wspólnoty.

Skupiając się jedynie na niezłomnym oporze i buncie całych rzesz społeczeństwa, narracja pomija kwestie szerokiej adaptacji Polaków do systemu, jej przyczyny oraz dalekosiężne konsekwencje tych działann' ${ }^{13}$.W tym wypadku "zapomnieniu”, a raczej świadomemu „wymazaniu” podlega zbiór postaw społecznych, które Józef Tischner określił mianem homo sovieticus ${ }^{14}$, a Leszek Kołakowski po prostu „poczuciem normalności”15. Wyraźna linia narracyjna i spójna opowieść nie dopuszczają wieloznaczności i sporów, które obecnie stanowią element dominujący w wypowiedziach zarówno bezpośrednich świadków wydarzeń, jak i zawodowych historyków zajmujących się tamtym okresem.

$\mathrm{Na}$ ekspozycję w ECS przeznaczono siedem sal, gdzie wykreowano opowieść, którą można oglądać (lub jej „doświadczyć”) zarówno w sposób chronologiczny, jak i tematyczny, jednak ten drugi rzadko sprawdza się w muzeach historycznych. „Akcja” zaczyna się strajkiem w Stoczni Gdańskiej, kończy

J. Staniszkis Antropologia władzy. Między traktatem Lizbońskim a kryzysem, Prószyński i S-ka, Warszawa 2009, s. 186-190.

K. Kersten Między wyzwoleniem a zniewoleniem. Polska 1944-1956, Aneks, Londyn 1993.

J. Tischner Homo sovieticus. Między Wawelem a Jasną Górq, "Tygodnik Powszechny” 24 czerwca 1990. Należy przy tym odróżnić pojęcie homo sovieticus upowszechnione w Polsce przez Józefa Tischnera czy Jerzego Turowicza oznaczające człowieka zniewolonego przez system i jednocześnie jego klienta, od pojęcia "człowieka sowieckiego", funkcjonującego w ZSRR oraz jego drugoobiegowej interpretacji autorstwa rosyjskiego pisarza i socjologa emigracyjnego Aleksandra Zinowjewa.

L. Kołakowski PRL-wesoły nieboszczyk?, "Tygodnik Powszechny” 12 lutego 1995. 
przemianami w całej Europie Środkowo-Wschodniej. Każde z pomieszczeń jest odpowiednio zatytułowane: „Narodziny Solidarności” - „Siła bezsilnych” - „Solidarność i nadzieja” - „Wojna ze społeczeństwem” - „Droga do demokracji” - „Triumf wolności” - „Kultura pokojowych przemian”. Już same tytuły sal wskazują na heroiczną walkę zakończoną zwycięstwem i sugerują optymistyczne przesłanie opowieści.

Typowym zabiegiem narracyjnym na ekspozycji jest kreacja podmiotu zbiorowego, „polskiego społeczeństwa”, w imieniu i za zgodą którego działa garstka opozycyjnych działaczy. Teoretycznie „bezsilni” (tytuł sali „Siła bezsilnych" pochodzi od eseju Vaclava Havla, który sprzeciwiał się w nim akceptacji systemu komunistycznego i odmawiał udziału w budowie socjali$\mathrm{zmu}^{16}$ ) w praktyce mieli moc, gdyż stała za nimi „prawda” (pisana w „Katalogu" zawsze dużymi literami). Społeczność lub naród (kategorie na wystawie synonimiczne) nie pozostają bierne, lecz stawiają opór, walcząc (manifestacje na ulicach) i tworząc „świetnie zorganizowane, podziemne alternatywne społeczeństwo"17. Ekspozycja podkreśla wyjątkową rolę Kościoła katolickiego w przemianach w Polsce. Narracja ma dwóch niekwestionowanych bohaterów jednostkowych: Lecha Wałęsę i Jana Pawła II, którego pielgrzymki do kraju są zawsze akcentowane jako wydarzenia o dużym znaczeniu politycznym.

Oprócz bohaterów pozytywnych narracja tożsamościowa wymaga zdefiniowania wroga. To dzięki niemu historia heroizmu może potwierdzić swoją wagę i znaczenie. Jak wykazują badania europejskich ekspozycji, zasady kreowania postaci wroga na wystawach muzealnych są z reguły zgodne z obowiązującym paradygmatem narracji historycznych, a na obraz ten wpływają ponadto: dyskurs pamięci, kulturowe stereotypy, polityka historyczna, głębokie struktury kulturowe, np. religia, czyli (uogólniając) mechanizmy historyczne, psychologiczne i socjologiczne. Co ciekawe, sam wróg (ewentualnie „obcy") nie jest tak ważny, jak relacja i dynamika/napięcie: wróg - bohater stanowiąca w wielu przypadkach fundament narracji muzealnej ${ }^{18}$.

Jak napisałam powyżej, wystawa w ECS po stronie prawdy, moralności i etyki sytuuje „polskie społeczeństwo", przeciwnik pozostaje jednak niedookreślony. Pojawiają się nazwiska, które mają wymiar symboliczny, jak

16 J. Kufel Siła bezsilnych, w: Wystawa stała Europejskiego Centrum Solidarności. Katalog, s. 54.

17 P. Ruchlewski Wojna ze społeczeństwem, w: Wystawa stała Europejskiego Centrum Solidarności. Katalog, s. 127.

18 Zob. The Enemy on Dispaly. The Second World War in Eastern European Museums, ed. by Z. Bogumił, J. Wawrzyniak, T. Buchen, Ch. Ganzer, M. Senina, Berghahn, New York-Oxford 2015. 
Wojciech Jaruzelski wprowadzający stan wojenny, a także narodowo „obcy”, czyli sowieci, jednak zasadniczo mamy na wystawie do czynienia z wrogiem bezosobowym pod postacią systemu komunistycznego. Wrogi system cechuje się na ekspozycji charakterystycznym dla totalitaryzmu zestawem atrybutów: brutalnością, militarnością (ZOMO), bezdusznością, anonimowością, pragnieniem wszechwładnej kontroli, dążeniem do utrzymania władzy za wszelką cenę. Ten zabieg szczególnie służy kreacji narracji tożsamościowej, która nie może wyłączać całych grup społecznych przyznając, że przeciwnikiem w niedawnej przeszłości była również część społeczeństwa polskiego utożsamiająca się z systemem lub nim zarządzająca. Ewentualna dekonstrukcja obrazu wroga osłabiłaby całą opowieść, zniszczyła dychotomię, opowieść stałaby się mniej heroiczna i mniej przekonująca. Co gorsza, wniosłoby to źle widzianą relatywność zagrażającą istnieniu dyskursu tożsamościowego ${ }^{19}$.

Muzeum II Wojny Światowej obejmuje swoją narracją długi okres w dziejach (1933-1989) i odnosi się nie tylko do różnych czasów, ale i kultur (np. totalitaryzm japoński), co niewątpliwie utrudnia zbudowanie jednej, spójnej linii narracyjnej. Wystawa rozpoczyna się od przedstawienia kryzysu systemów demokratycznych po I wojnie światowej oraz kształtowania pierwszych autorytarnych reżimów i zostaje doprowadzona aż do 1989 roku, obejmując również okres powojenny i czasy „żelaznej kurtyny”. Oczywiście główna treść ekspozycji obejmuje terror II wojny światowej, jednak ważne dla twórców było pokazanie zarówno jej genezy, jak i długofalowych konsekwencji. Narracja ma układ chronologiczny, ale niektóre elementy przeszłej rzeczywistości pokazane są w sposób pogłębiony, problemowy.

Podobnie jak w ECS podmiot narracji w MIIWŚ jest zbiorowy, jednak różnica jest zasadnicza, ponieważ w tym drugim przypadku nie są to walczący bohaterowie, ale cywilne, często zapomniane lub marginalizowane ofiary. W muzeach wojennych mamy zasadniczo do czynienia z dwiema różnymi grupami ofiar, które można określić jako heroiczne lub martyrologiczne.

Pierwsza grupa to bohaterowie walczący i ginący w imię dających się uzasadnić celów ogólnonarodowych (lub jeszcze wyższych, uniwersalnych, jak wolność czy honor). Giną, ale jednocześnie odnoszą moralne zwycięstwo, a upamiętnienie jest złożeniem należnego im hołdu. Grupa druga to ofiary sensu stricto, przypadkowe i bezsensowne (przez co rozumiem, że ich śmierć nie da się sensownie zracjonalizować, nie podlega heroizacji i nie można jej pozytywnie wartościować). Oprócz zamordowanych w czasie Zagłady Żydów, 
Romów i innych grup narodowościowych wymienić tu można cywilne ofiary okupacji, pacyfikacji, wypędzeń etc. Ich upamiętnienie to bardziej zachowanie w pamięci oraz refleksja nad mechanizmami, które doprowadziły do zbrodni.

Ofiary heroiczne dominują w muzeach związanych tematycznie z II wojną światową (np. w Muzeum Powstania Warszawskiego, Armii Krajowej, Muzeum Katyńskim czy Muzeum Więzienia Pawiak), gdyż są dla wspólnoty powodem do dumy przybierającej czasem rozmiary megalomanii ${ }^{20}$. Pokonanych bohaterów czci się i stawia za wzór do naśladowania. Cierpienie ofiar heroicznych jest pozytywnie waloryzowane, a ich historia często staje się fragmentem szerszej opowieści stanowiącej mit fundacyjny niepodległej, odrodzonej wspólnoty (jak w przypadku żołnierzy Armii Krajowej). Najważniejszym elementem wystaw są zatem czyny pokonanych, ich bohaterska walka, a nie sama śmierć.

Ofiary martyrologiczne upamiętniane są głównie w muzeach Zagłady lub miejscach pamięci, gdzie „poznajemy” je w momencie śmierci. Właśnie o tę grupę ofiar upomina się Muzeum II Wojny Światowej, które w swojej narracji podkreśla wyjątkowość wojny poprzez tragiczny los ludności cywilnej²1. Paweł Machcewicz i Piotr Majewski piszą jednak: „[...] nie zamierzamy tworzyć muzeum martyrologii narodu polskiego, ani muzeum chwały polskiego oręża, lecz placówkę o przesłaniu uniwersalnym, w której wydarzenia rozgrywające się w Polsce stanowiłyby jedynie część szerszego obrazu"22. Martyrologia ofiar nie jest zatem ani jedynym, ani głównym celem przekazu Muzeum II Wojny Światowej, to tylko jedna z obecnych tam perspektyw narracyjnych, jednak nietrudno zauważyć, że dominująca.

Interesująca jest również narracyjna koncepcja wrogów, gdyż nie są nimi, najczęściej w takich razach występujący, obcy, w tym przypadku Niemcy lub Sowieci. W MIIWŚ głównym, siejącym grozę i śmierć przeciwnikiem jest sama wojna jako zjawisko historyczne. Ekspozycja podzielona jest na trzy główne części zatytułowane „Droga do wojny”, „Groza wojny” i Długi cień wojny", które przedstawiają najbardziej tragiczne, a nie heroiczne doświadczenie wojny będące udziałem milionów ludzi. Niezwykle przy tym istotne

J.M. Piskorski Od kultu herosów do adoracji ofiar. Przemiany w kulturze pamięci, "Więź" t. 53, nr 2/3, 2010, s. 5 . Zob.www.muzeum1939.pl/pl/o_muzeum/zalozenia/misja_i_cele (09.04.2016).

22 P. Machcewicz, P. Majewski Muzeum II Wojny Światowej.Zarys koncepcji programowej, „Przegląd polityczny" $2008 \mathrm{nr}$ 91/92, s. 47. 
dla narracji jest pokazanie splotu okoliczności, które mogą doprowadzić do szeroko zakrojonych konfliktów. Czynniki te są ważniejsze od postaci tyranów czy dyktatorów, którym narracja nie przypisuje ich tradycyjnej demonicznej roli. Wrogami są również zjawiska zwykle towarzyszące wojnie: głód, korupcja, kolaboracja etc. Nie pominięto też długofalowych następstw wojny, czyli przesiedleń, wypędzeń, zniszczeń, nierozliczenia zbrodniarzy oraz trwającego przez dekady podziału świata.

\section{Obiekty i techniki wystawiennicze}

Ekspozycje narracyjne dominujące obecnie w wystawiennictwie historycznym znoszą centralną rolę autentycznych obiektów w dyskursie muzealnym, pozwalając zastąpić je kopiami, aranżacjami czy rekonstrukcjami, które lepiej sprawdzają się w wywoływaniu u widzów emocji oraz symulowaniu kontaktu z przeszłą rzeczywistością. Zarówno ECS, jak i MIIWŚ podkreślają jednak wagę autentycznych przedmiotów, uznając je za centralny punkt swoich opowieści. Mamy więc do czynienia z muzeami hybrydowymi, które łączą tradycyjny szacunek dla obiektu materialnego z formalną atrakcyjnością wystawy.

Wobec braku gotowych kolekcji związanych z „Solidarnością” twórcy wystawy w ECS odnajdywali i zdobywali pamiątki (głównie fotografie), przede wszystkim były to indywidualne dary ze zbiorów prywatnych. Z ponad dwóch tysięcy obiektów jako najcenniejsze wymienia się: transparent „Proletariusze wszystkich krajów łączcie się", który wisiał nad Bramą nr 2 podczas sierpniowego strajku, strajkowy sweter Lecha Wałęsy, matryce offsetowe „Strajkowego Biuletynu Informacyjnego «Solidarność»", materiały i urządzenia poligraficzne, transparenty, flagi, opaski strajkowe, pieczęcie znaczki, suwnicę, na której pracowała Anna Walentynowicz, oraz inne obiekty małogabarytowe ${ }^{23}$.

Najważniejsze obiekty o statusie ikonicznym to tablice ze spisanymi postulatami strajkujących oraz brama nr 2 Stoczni Gdańskiej, znajdująca się na zewnątrz budynku, stanowiąca jednak integralny element narracji (bramę można oglądać z okien sal wystawowych). Właśnie te dwa obiekty idealnie realizują misję ECS, która zakłada wpisanie „Solidarności” w pamięć Europy. Są duże i rozpoznawalne w świecie. Ta pierwsza cecha, wbrew pozorom, jest niezwykle istotna w przypadku rekonstrukcji historycznych

23 K. Knoch Europejskie Centrum Solidarności. Wyzwania w trakcie realizacji jednej z największych w Polsce wystaw narracyjnych o najnowszej historii Polski i Europy „ "Światowid. Rocznik Muzeum PRL-U (w organizacji)” 2014 nr 1, s. 117-118. 
dotyczących zjawisk lub procesów, dla których trudno znaleźć spektakularne dowody materialne, a te istniejące są trudne do wystawienia ze względu na swoją „zwyczajność”. Takie elementy ekspozycji jak kaski, stoły z Sali BHP, karty czasu pracy czy narzędzia stoczniowe nie mają siły przyciągania równej obiektom wartościowym, przy czym przez wartość rozumiem nie tyle cenę, co wyjątkowość, która sprawia, że dany obiekt łatwo staje się muzealnym eksponatem i może być odbierany na poziomie poznawczym lub estetycznym.

Muzeum II Wojny Światowej również poszukiwało cennych obiektów, jednocześnie jednak zadbano o scenografię i teatralizację przestrzeni muzealnej. Budynek zaprojektowano tak, by cała powierzchnia wystawiennicza znajdowała się pod ziemią, co otworzyło możliwości wzmocnienia dramaturgii, choćby za pomocą oświetlenia. Na pięciu tysiącach metrów kwadratowych przestrzeni ekspozycyjnej zgromadzono dwa tysiące eksponatów. Oprócz typowych dla wystaw wojennych obiektów militarnych pokazano również bardzo interesujące przedmioty ilustrujące, jak głęboko ideologia wrastała w codzienność $\mathrm{i}$ ją kształtowała, np. bombki choinkowe ze znakiem swastyki czy sowiecką grę planszową „Plan pięcioletni”.

W obu muzeach użyto na ekspozycji tzw. zabytków drugiej kategorii, które nie mają dużej wartości artystycznej, a niekiedy nawet i historycznej, ale ich celem jest potwierdzenie realności przeszłości oraz jej legitymizacja. Zabytki te tworzą, jak określa to Andrzej Szpociński, „przestrzeń historyczną”. Materialność wytworu jest najistotniejsza i potwierdza w sposób niepodważalny „dawność". W przypadku zabytków o wielkiej wadze i doniosłości historycznej lub artystycznej te ich wartości przesłaniają inne funkcje $\mathrm{e}^{24}$.

Od strony formalnej obie wystawy są realistycznymi rekonstrukcjami przeszłości z pretensjami do neutralności i obiektywizmu. Oprócz tradycyjnych metod ekspozycyjnych, czyli artefaktów z epoki, prezentują najnowsze rozwiązania technologiczne. Zwiedzający mają dostęp do projekcji elektronicznych, gdzie zgromadzone są fotografie, filmowe materiały archiwalne, dokumenty, mapy, biogramy, kalendaria czy wycinki prasowe. Chodzi tu o kreację co najmniej dwóch poziomów narracji: pierwszego, bazowego, opartego na tekstach, obiektach i archiwaliach, oraz drugiego, głębszego, wykorzystującego multimedia, dotykowe ekrany z bazami danych.

24 A. Szpociński Autentyczność przeszłości jako problem kultury współczesnej, w: Wobec przyszłości. Pamięć przeszłości jako element kultury współczesnej, red. A. Szpociński, Instytut im. Adama Mickiewicza, Warszawa 2005, s. 299. 
Scenograficznie i dramaturgicznie dużo lepiej dopracowane jest MIIWŚ, prezentując przestrzeń wizualnie zróżnicowaną, budującą napięcie dzięki technikom teatralizacji oraz umiejętnie stwarzającą atmosferę zagrożenia. Europejskie Centrum Solidarności, odżegnując się od zabiegów scenograficznych, które twórcy wystawy uznają za „nachalną narrację"25, ostatecznie tworzy ekspozycję bardzo nierówną. Niektóre fragmenty (np. „Wojna ze społeczeństwem") są dynamiczne, niczym kadr filmowy, inne jednak są słabsze, momentami nużące (np. „Solidarność i nadzieja”). Trzeba też zaznaczyć, że w ECS sale wystawowe są prostokątne z oknami wpuszczającymi światło dzienne, co z perspektywy budowania ekspozycji nie jest szczególnie dogodne.

\section{Zakres tematów}

W ECS heroiczna opowieść o polskiej bezkrwawej rewolucji opiera się głównie na wybranych wydarzeniach politycznych. „Akcja” rozpoczyna się przełomowym, z perspektywy wystawy, strajkiem w stoczni i podpisaniem porozumień sierpniowych, a następnie rozwija się opowieść o „ostatniej polskiej konfederacji”, „pospolitym ruszeniu” toczącym „zwycięskie batalie bez użycia przemocy" pod "niekwestionowanym" przywództwem Lecha Wałęsy, cieszącego się „ogromnym autorytetem wśród społeczeństwa"26. Wystawa nie poświęca zbyt wiele uwagi życiu codziennemu szerokich rzesz ludności czy kulturze popularnej minionej epoki. Spośród wielu zjawisk kulturowych autorzy koncepcji prezentują jedynie te o zabarwieniu politycznym, np. Pomarańczową Alternatywę, ruch artystyczno-opozycyjny stworzony przez Waldemara „Majora” Frydrycha, Ruch „Wolność i Pokój” utworzony w 1985 roku, Federację Młodzieży Walczącej. Reprezentacje życia codziennego ograniczono do skrótowego pokazania negatywnych wymiarów politycznego i ekonomicznego uzależnienia od ZSRR. Nawet prezentacja „typowego mieszkania w bloku" w narracji przewodnika wiąże się z istnieniem „małych enklaw wolności", co symbolizuje stojące na komodzie radio, z którego dobiegają odgłosy audycji „Wolna Europa".

Muzeum II Wojny Światowej, oprócz naturalnych dla muzeów wojennych prezentacji wszelkiego rodzaju militariów oraz przebiegu samego konfliktu zbrojnego, szeroko uwzględnia życie codzienne szeregowych żołnierzy

25 J. i B. Szymańscy Powstawanie wystawy stałej, w: Katalog, s. 257.

26 K. Knoch Solidarność i nadzieja, w: Katalog, s. 87. 
i ludności cywilnej. Poza terrorem, poniżeniem, głodem, pracą niewolniczą ekspozycja odzwierciedla niebywałą wolę przetrwania i oporu (zbrojnego i cywilnego) społeczeństw krajów dotkniętych globalnym konfliktem. Co bardzo istotne, wystawa pokazuje również, że bohaterskie zachowania konkretnych osób nie zawsze były doceniane, wręcz przeciwnie, skutkowały cierpieniem i upokorzeniem nawet po zakończeniu wojny (np. Kazimierz Moczarski, który okupił swą patriotyczną działalność w czasie wojny sowieckim więzieniem). Ekspozycja mierzy się również z mitycznym obrazem Polski przedwojennej, pokazując nierówności społeczne oraz wzrost antysemityzmu w okresie przedwojennym.

Mimo że przesłanie wystawy pobrzmiewa banalnym „nigdy więcej”, pokazanie tragicznego i uniwersalnego doświadczenia wojny z perspektywy innej niż chwalebne czyny na polach bitew jest niezwykle cenne. Wielkim atutem jest również próba zarysowania wielowymiarowych przyczyn światowego konfliktu.

\section{Zderzenie paradygmatów}

Europejskie Centrum Solidarności jest muzeum otwarcie deklarującym cele tożsamościowe. Budowanie pamięci zbiorowej Polaków odbywa się tam na podstawie retrospektywnej heroizacji przeszłości. Umieszczając ECS w szerszym kontekście, możemy ocenić je przez pryzmat dwóch zjawisk: muzeum romantycznego (odwołującego się do przeszłości) i narodowego brandingu (ukierunkowanego na przyszłość).

Muzeum romantyczne ${ }^{27}$ cechuje przewaga czynników emocjonalnych nad intelektualnymi, przemawianie do wyobraźni, patriotyzm (czasem bliski egzaltacji), zaangażowanie polityczne w walce o wolność i niepodległość, kult bohaterów, niekiedy także pojawianie się motywów literackich. Zasadnicza idea, którą reprezentuje ECS, to nieśmiertelność narodu pod warunkiem

27 Romantyczny nurt muzealnictwa polskiego zrodził się w Puławach pod koniec XVIII wieku wraz ze zrealizowanym pomysłem Izabeli Czartoryskiej na muzeum narodowe (Sybilla) odwołujące się do czynników emocjonalnych, takich jak miłość ojczyzny, tęsknota do wolności, szacunek dla własnej narodowej twórczości, do własnego narodowego stylu i obyczaju oraz uczucie czci i mistycznej wiary wobec tzw. skarbów lub pamiątek narodowych (państwowe symbole, znaki, dokumenty). Zdzisław Żygulski określił tę tendencję polityczno-patriotyczną, Z. Żygulski (jun.) Nurt romantyczny w muzealnictwie polskim, w: Originalveröffentlichung, w: Romantyzm: studia nad sztuka 2. połowy XVIII wieku i wieku XIX. Materiały sesji Stowarzyszenia Historyków Sztuki, PWN], Warszawa 1963-1967, s. 52. 
zachowania tożsamości i woli walki o przetrwanie. Nie jest wobec tego zaskoczeniem, że „Solidarności” ECS przypisuje, nieco na wyrost, dalekosiężne pozytywne zmiany w mentalności społeczeństwa polskiego: ruch miał być „szkołą demokracji”, ,miliony” Polaków dzięki niemu brały udział w debacie publicznej, był to „czas ogromnej aktywności, zwoływania zebrań, wieców, nieustannych dyskusji, debat i obrad"28. Celem ekspozycji jest podnoszenie rangi narodowej godności. Język opowieści jest podniosły, odwołuje się do kategorii dobra i zła oraz racji moralnych. Narracja w ECS wpisuje mesjanistyczną opowieść o bohaterskich czynach z moralnym przesłaniem nie tylko w heroiczną historię Polski, ale - a może przede wszystkim - świata ${ }^{29}$.

Muzeum tworzy pozytywny autowizerunek Polaków, realizując cele, które głosi tzw. nowa polityka historyczna. Jan Ołdakowski, dyrektor Muzeum Powstania Warszawskiego, pisze: „Polacy wreszcie zauważyli, że bez sensu jest dalsze czekanie, by ktoś pięknie opowiedział naszą historię XX wieku, podkreślił nasz wysiłek i bohaterstwo. [...] Podstawowym obowiązkiem wspólnoty jest samodefiniowanie się i opowiadanie o sobie na zewnątrz. Historia jest jednym z elementów składowych tej opowieści"30. Według tej koncepcji państwo powinno być aktywne w kwestiach związanych z pamięcią i świadomością historyczną obywateli, musi przejąć odpowiedzialność za kształtowanie narracji o przeszłości zgodnych z bieżącą racją stanu.

W przypadku ECS można więc mówić o narodowym brandingu. Autorzy koncepcji piszą o tym otwarcie: „Chcieliśmy pokazać Solidarność jako pozytywny ruch, który wpłynął na kształt współczesnej Europy. Pragnęliśmy przekazać prosty komunikat: zaczęło się w Polsce, zaczęło się w Gdańsku.

28 Ponadto "Solidarności" przypisuje się wygranie batalii o pamięć historyczną, o czym mają świadczyć pomniki powstałe z datków społecznych: Poległych Stoczniowców 1970 w Gdańsku, Ofiar Grudnia 1970 roku w Gdyni, Ofiar Czerwca 1956 roku w Poznaniu, zob. K. Knoch Solidarność i nadzieja, w: Katalog, s. 89-90. Jednak nietrudno zauważyć, że w obecnych dyskusjach politycznych batalia o pamięć historyczną wciąż trwa, a Okrągły Stół i postać Lecha Wałęsy stanowią tu najbardziej gorące i kontrowersyjne punkty. Rytuały składania kwiatów czy oddawania hołdu przy pomnikach to jedynie zewnętrzne objawy szacunku do przeszłości, do której różne grupy przywiązują różne znaczenia. „Tradycyjne" polskie "umiłowanie wolności” czy "społeczeństwo obywatelskie" w praktyce można przypisać jedynie części wspólnoty.

Jacek Kołtan pisze w Katalogu: „Ruch Solidarności w Polsce oraz pokojowe rewolucje w większości krajów Europy Środkowej i Wschodniej wpisują się w tradycję pokojowego rozwiązywania społecznych i politycznych konfliktów". J. Kołtan Kultura pokojowych przemian, w: Katalog, s. 245 .

30 P. Kosiewski, J. Ołdakowski Muzeum na nowo pomyślane, "Tygodnik Powszechny" 23 kwietnia 2012. 
Innym ważnym celem - jakkolwiek to prozaicznie i trywialnie zabrzmi, a niektórych oburzy - było promowanie najlepszej polskiej marki, jaką jest Solidarność" ${ }^{\prime 11}$ Jednym z zasadniczych elementów brandingu narodowego jest identyfikacja zagadnień kluczowych oraz pokazanie rytuałów, obrazów i symboli sytuujących dany naród w określonej przestrzeni, odróżniający go od innych. W przypadku tożsamości narodowej branding oznacza proces przypisywania danej wspólnocie wyjątkowej identyfikacji poprzez podkreślanie pewnych (pozytywnych) znaczeń i mitów oraz ignorowanie innych. Ten proces wspierany jest polityką państwową i ma na celu wyróżnienie się w zglobalizowanym świecie oraz korzyści ekonomiczne związane z turystyką, inwestycjami, kreowaniem miejsc pracy itp. Branding może być bardzo skuteczną strategią w ich osiąganiu, przy czym „komercyjny” charakter terminu nie oznacza, że praktyka nie może być aktem symbolicznym, reprezentacją rzeczywistości społecznej i politycznej².

Wystawa w MIIWŚ reprezentuje niezwykle istotną paradygmatyczną zmianę w opowieści o przeszłości. Zamiast romantycznej (afirmatywnej) narracji o bohaterskim narodzie kreuje przekaz krytyczny i realistyczny, chociaż nie naturalistyczny (muzeum nie epatuje okrucieństwem), co stawia pod znakiem zapytania zbiorowy heroizm jako wzór tożsamościowy. W przypadku MIIWŚ tradycja romantyczna przestaje być jednoczącą naród metanarracją, następuje decentralizacja i fragmentaryzacja pamięci zbiorowej.

Los polskiego społeczeństwa (podobnie jak Zagłada Żydów) pokazany jest na szerokim tle i w kontekście globalnego chaosu i cierpień spowodowanych wojną. Terror światowego konfliktu wymierzony jest w różne grupy ofiar bez względu na narodowość (np. radzieccy jeńcy wojenni). Oprócz fizycznego wyniszczenia wystawa pokazuje inne elementy doświadczenia wojennego, jak deportacje, przymusową pracę niewolniczą i obozy koncentracyjne. Oprócz wyjątkowej na wielką skalę organizacji Polskiego Państwa Podziemnego prezentuje różne oblicza kolaboracji i współpracy z wrogiem. Bohaterski opór to nie tylko walka zbrojna i działania dywersyjne, ale również sabotaż cywilny oraz oddolne, obywatelskie inicjatywy. Losy pojedynczych wyróżnionych na wystawie bohaterów pokazują, że nawet w najgorszych warunkach można pozostać przyzwoitym człowiekiem i zdobyć się na czyny heroiczne, jednak

31 J. i B. Szymańscy Powstawanie wystawy stałej, w: Katalog, s. 259.

32 M. Aronczyk New and improved nations. Branding national identity, www.culturaldiplomacy. org/academy/content/articles/events/nationbranding/participant-papers/New-And-Improved-Nations_-_Melissa-Aronczyk.pdf(1.08.2020). 
nie należy się za to spodziewać nagrody. Ekspozycja nie ma punktów kulminacyjnych ani szczęśliwego zakończenia, nie oferuje też katharsis, na wojnie wszyscy są przegrani.

Wystawa nie uniknęła banalizacji, szczególnie we fragmencie reprezentującym Zagładę Żydów. Takie obiekty jak dziecięce buciki, pasiaki, klucze do opuszczonych domów czy wagon symbolizujący deportacje należą do „żelaznego" zestawu ikonicznych eksponatów prezentowanych prawie we wszystkich muzeach Zagłady. Z drugiej jednak strony nie brakuje rozwiązań nowatorskich oraz tematów i obiektów kontrowersyjnych (np. masowe gwałty na Niemkach pokazano na wystawie przez zaprezentowanie ruchomej figurki o tematyce erotycznej, wykonanej przez żołnierza Armii Czerwonej). Wreszcie, co najważniejsze, po raz pierwszy w polskim muzealnictwie udało się stworzyć spójną narrację, która równą miarą mierzy zachodni (ale też japoński) faszyzm i wschodni komunizm. Kreśli fragment historii Polski, której równoprawną częścią jest zarówno Zagłada żydowskich obywateli II RP, jak i ofiary sowieckiego terroru oraz rzezi na Wołyniu.

Głównym zarzutem wobec MIIWŚ, jaki sformułowali przedstawiciele tzw. nowej polityki historycznej, był brak wyraźnej polskiej linii narracyjnej oraz „polskiego punktu widzenia”. W wysuwanych postulatach nie chodziło o deficyt informacji na temat polskiego doświadczenia wojennego, gdyż stanowią one znakomitą większość treści ekspozycji, ale o nieobecność szczególnej perspektywy w muzealnej wypowiedzi, tworzącej narrację tożsamościową, która mogłaby stanowić mit fundacyjny narodu polskiego. Chodzi tu o dyskurs odwołujący się do takich pojęć jak heroizm i martyrologia czyli-zgodnie z określeniem Marii Janion - wykładni romantycznej lub symboliczno-romantycznej. Janion uznaje, że dominujący w ciągu prawie dwustu lat (od epoki porozbiorowej poczynając, a na stanie wojennym i okresie po nim kończąc) romantyzm, jako jednolita i wszechogarniająca koncepcja i praktyka kultury, budował w tym czasie poczucie tożsamości narodowej i bronił symboli tej tożsamości, co ostatecznie spowodowało, że nabrał charakteru charyzmatu narodowego ${ }^{33}$. Mimo że badaczka wieści kres tego paradygmatu, nie wszyscy uznają, że wyczerpał on swoje możliwości, wręcz przeciwnie, niektórzy dziennikarze, politycy i historycy widzą nadal w tym modelu jeden z podstawowych elementów budowania wspólnoty oraz poczucia dumy z narodowej przeszłości i przyszłości. Szczególnie dotyczy to takich zjawisk

33 M. Janion Zmierzch paradygmatu http://biblioteka.kijowski.pl/janion\%2omaria/co\%2oprze\%BFy\%B3e\%9C.pdf (10.05.2017). 
jak wojna czy powstania zbrojne. Piotr Semka w swojej analizie MIIWŚ pisze: „Owszem, nikt o zdrowych zmysłach nie zaprzecza, że wojna niesie ze sobą grozę, ale nieprzypadkowo czcimy ludzi, których ta wojenna groza nie skłania do bierności, tchórzostwa, serwilizmu wobec najeźdźców, zamknięcia się wyłącznie na walce o przetrwanie swoje i ewentualnie bliskich. Opowiadając o wojnie, nie należy ukrywać potworności, ale akcentuje się też hartowanie się charakterów, pomysłowość oporu i solidarność społeczną. A także to, co zawsze fascynowało ludzi - format dowódców, jakość taktyki wojennej i odwagę na polu bitwy"34. Konflikt, jaki się tu rysuje, odzwierciedla zderzenie dwóch modeli muzealnej reprezentacji historycznej.

Przedstawiając przeszłość na ekspozycji muzealnej, można zaakcentować wyjątkową ścieżkę danej wspólnoty i traktować ją jako nadzwyczajną lub pokazać, że konkretny naród partycypuje w czymś o szerszym, nawet uniwersalnym zasięgu, że istnieją pewne zjawiska (złe i dobre), które dotyczą wszystkich ludzi.

W pierwszym przypadku kreuje się model afirmatywny, co ma określone konsekwencje. Budowanie poczucia dumy z narodowej historii okupione jest wymazaniem tych elementów przeszłości, które nie pasują do pozytywnego wizerunku narodowego. W ten sposób skazuje się je na zapomnienie. Wyraźna i spójna linia narracyjna wyklucza alternatywne interpretacje. Czarno-biały obraz przeszłości i jednostronna interpretacja ułatwiają kreację silnego poczucia jedności w obrębie narodu, nie pomagają jednak w krytycznym myśleniu, dystansowaniu się od przeszłości i rozumieniu złożonych procesów historycznych.

W drugim przypadku jest szansa na zbudowanie muzeum krytycznego, które oprócz dziejów chwalebnych prezentuje również dziedzictwo trudne. Muzea zachodnie coraz częściej realizują podobną koncepcję, wychodząc z założenia, że historie konfliktów, wykluczeń, walk, dominacji, ludobójstwa, kolonizacji (tzw. challenging history) są również elementami historii narodowych. Jest to spore wyzwanie zarówno dla instytucji, jak i publiczności, jednak relacja między muzeum a odwiedzającymi nie może polegać na byciu arbitrem w osądzaniu, co jest „obiektywną historią" lub co powinno zostać stałym elementem pamięci zbiorowej ${ }^{35}$. Na pytanie, czy muzeum jest

34 Muzeum II Wojny Światowej. Analiza Piotra Semki, www.rp.pl/Plus-Minus/308119920-MuzeumII-Wojny-Swiatowej-Analiza-Piotra-Semki.html (02.02.2020).

35 Zob. Challenging History in the Museum International Perspectives, ed. by J. Kidd, S. Cairns, A. Drago, Routledge, London 2016. 
miejscem dla ambitnej, trudnej w odbiorze reprezentacji przeszłości, należy w kontekście „nowej muzeologii” odpowiedzieć twierdząco. Badania publiczności przeprowadzone przez Fionę Cameron (w Australii, Nowej Zelandii, Kanadzie, Stanach Zjednoczonych i Wielkiej Brytanii) pokazały, że wielu odwiedzających otwartych jest na ten model wystawiennictwa, a nawet uznaje, że to misja i odpowiedzialność muzeum jako instytucji. Oczywiście są również grupy osób, którym podobne projekty wydają się zbyt kontrowersyjne ${ }^{36}$. Wprowadzenie tematów trudnych na ekspozycję sprawia, że przesuwają się one ze strefy prywatnej do publicznej oraz prowokują do dyskusji, która w ostateczności wpływa na wrażliwość i świadomość społeczną. Tutaj niezbędna jest transparentność kuratorskich decyzji oraz wyjaśnienie publiczności, przed jakim wyborem stanęli twórcy oraz dlaczego zdecydowali się na ten, a nie inny zestaw tematów. W wielu przypadkach dzięki muzeum możliwa jest zmiana w postrzeganiu tematów kontrowersyjnych na akceptowalną wizję przeszłości.

Wystawa krytyczna wychodzi od innych pytań niż afirmatywna. Dotyczą one nie tylko wydarzeń, które należy przedstawić, i jak to zrobić, by wiedza wydawała się obiektywna i naukowo uprawomocniona, ale również tego, kto jest „właścicielem” przeszłości, kogo dana narracja obejmie, kogo wykluczy, czyje wspomnienia uprzywilejowuje, a czyje pominie. Ważny jest również namysł nad sposobem połączenia indywidualnych pamięci z ogólną narracją historyczną. Warto pokazać wydarzenia z różnych perspektyw, włączyć do ekspozycji głosy osób wcześniej nieuwzględnianych. Wieloperspektywiczność ekspozycji pozwala każdemu z widzów odnaleźć tematy interesujące i korespondujące z jej/jego światopoglądem, co neutralizuje ewentualną niezgodę na niektóre tezy kuratorów. Wielość problemów i aspektów związanych z wojną ułatwia zbudowanie własnej narracji i oceny oraz wprowadzenie tematów nieoczywistych do sfery publicznej.Ta ostatnia,jak zakłada Michael Rothberg, nie jest dobrem ograniczonym i mogą w niej zachodzić interakcje między różnymi pamięciami i poglądami. Rothberg postuluje odrzucenie modelu pamięci rywalizującej, w której przestrzeń publiczna jest z góry dana i limitowana, a określone w niej dyskursy „walczą na śmierć i życie”. W zamian za to zachęca do myślenia o przestrzeni publicznej jako „elastycznej przestrzeni dyskursywnej, w której poszczególne grupy nie tyle wyrażają

36 Zob. F. Cemron Transcending fear - engaging emotion \& opinion - a case for museums in the 21st century, http://citeseerx.ist.psu.edu/viewdoc/download?doi=10.11.462.4087धrep=rep1Etype$=\operatorname{pdf}(04.04 .2019)$. 
wcześniej sformułowane stanowiska, ile w zasadzie wytwarzają siebie przez dialogiczne interakcje z innymi: zarówno podmioty, jak i przestrzenie publiczne otwarte są na nieustające rekonstrukcje" ${ }^{137}$.

Europejskie Centrum Solidarności przemawia językiem narodowym i niejako wbrew współczesnym procesom kulturowym stara się swoją heroiczną i tożsamościową narracją przywrócić do życia romantyczną wizję polskiej historii.Z jednej strony ma zadanie ułatwione, gdyż symbolika, którą się posługuje, jest bardzo dobrze zakorzeniona w polskiej kulturze i znana wszystkim odwiedzającym, z drugiej jednak wystawa wpływa bardziej na pamięć zbiorową o przeszłości niż na wiedzę o niej. Muzeum II Wojny Światowej zaprezentowało ekspozycję wieloperspektywiczną, trudniejszą w odbiorze, otwartą na tematy trudne i kontrowersyjne. Ceną były oskarżenia o "antypolski" charakter i ostatecznie utrata autonomii instytucji. Mimo to wydaje się, że to lepsza droga do budowania autorytetu kulturowego i zaufania publiczności.

37 M. Rothberg Pamięć wielokierunkowa. Pamiętanie Zagłady w epoce dekolonizacji, przeł. K. Bojarska, Wydawnictwo IBL PAN, Warszawa 2015, s. 19. 


\section{Abstract}

\section{Anna Ziębińska-Witek}

MARIA CURIE-SKŁODOWSKA UNIVERSITY (LUBLIN)

The Past in Museums - Two Models of Representation: A Comparative Analysis of the European Solidarity Centre and the Museum of the Second World War in Gdańsk

Ziębińska-Witek analyses and deconstructs the museum narratives of two historical museums in Gdańsk. The material examined are the exhibitions at the European Solidarity Centre and the Museum of the Second World War, which are interpreted using the methods of visual studies (analyses of the composition, content, material objects and meanings). Based on this Ziębińska-Witek highlights two basic models of creating a vision of the past through museum exhibitions: the romantic and the critical model. Despite the fact that both institutions represent the contemporary museological trend of creating an "experience" and engaging the public on an emotional level, they differ widely both in the way they describe reality and in their perception of the museum's function as a cultural institution.

\section{Keywords}

historical museum, representation, exhibition models, European Solidarity Centre, Museum of the Second World War, museology 